\title{
Application of chemical fractionation and X-ray powder diffraction to study phosphorus speciation in sediments from Lake Hongfeng, China
}

\author{
JIANG CuiHong, WU Di, HU JiWei", LIU Feng, HUANG XianFei, LI CunXiong \& JIN Mei \\ Guizhou Provincial Key Laboratory for Information System of Mountainous Areas and Protection of Ecological Environment, Guizhou Normal \\ University, Guiyang 550001, China
}

Received June 18, 2010; accepted November 22, 2010

\begin{abstract}
Based on the techniques of sequential extraction and X-ray powder diffraction (XRD), the distribution characteristics of phosphorus speciation were investigated in 13 sediment samples from Lake Hongfeng, an important drinking water source for Guiyang with a typical karstic limestone environment. The total phosphorus (TP) concentrations in the sediments ranged from 973.36 to $2334.18 \mathrm{mg} / \mathrm{kg}$ with a mean concentration of $1635.87 \mathrm{mg} / \mathrm{kg}$ (dry weight), and it was evident that the phosphorus level in the sediments was high compared with other eutrophic lakes such as Lake Chaohu and Lake Xihu. The results of the two methods, sequential extraction and XRD, demonstrated the presence of different phosphorus species in the lake sediments. Being compatible with local geophysical characteristics, the results of sequential extraction techniques indicate that the average percentages of dissolved phosphorus (DP), aluminum-bound phosphorus (Al-P), iron-bound phosphorus (Fe-P), calcium-bound phosphorus $(\mathrm{Ca}-\mathrm{P})$ and organic phosphorus $(\mathrm{OP})$ in the sediments were $0.40 \%, 7.06 \%, 5.07 \%, 45.48 \%$ and $38.49 \%$, respectively. Notably, the concentrations of inorganic phosphorus (IP) were higher than those of OP, and the IP consisted primarily of Ca-P. The high concentrations of $\mathrm{Ca}-\mathrm{P}$ may temporarily control the release of phosphorus from the sediments because it is a relatively stable, inert and non-bioavailable phosphorus fraction. The results of XRD analysis indicated that, among phosphorus species, $\mathrm{AlPO}_{4} \mathrm{was}$ found in all sediment samples at relatively high concentrations. Moreover, the TP concentrations in the sediments were high; thus the release potential and bioavailability of phosphorus in the sediments was important. Further statistical analyses of the results revealed significant correlations between phosphorus species in the sediments with two extractable principal components and four selectable cluster levels allowing interpretation of possible origins of phosphorus loading and transformation mechanisms of phosphorus species. Furthermore, available remediation measures were briefly assessed for the lake while considering its distinct environmental features.
\end{abstract}

eutrophication, karstic environment, lake sediments, phosphorus speciation, sequential extraction procedure, X-ray powder diffraction

Citation: Jiang $\mathrm{C} \mathrm{H}, \mathrm{Wu} \mathrm{D}, \mathrm{Hu} \mathrm{J} \mathrm{W}$, et al. Application of chemical fractionation and X-ray powder diffraction to study phosphorus speciation in sediments from Lake Hongfeng, China. Chinese Sci Bull, 2011, 56: 2098-2108, doi: 10.1007/s11434-011-4541-9

Lake Hongfeng (E $106^{\circ} 24^{\prime}-106^{\circ} 43^{\prime}$, N 26 $31^{\prime}-26^{\circ} 34^{\prime}$ ) is located about $32 \mathrm{~km}$ west of Guiyang, the capital of Guizhou Province, in southwestern China. The local geology consists of typical karstic limestone terrain that is rich in phosphate rock deposits. The lake is the largest deep artificial reservoir on the Yunnan-Guizhou Plateau, with an

*Corresponding author (email: jwhu@ gznu.edu.cn) average water depth of $10.5 \mathrm{~m}$ (max. $45 \mathrm{~m}$ ), a flood storage capacity of $6.01 \times 10^{8} \mathrm{~m}^{3}$ and an area of $57.2 \mathrm{~km}^{2}$. It is a typical seasonal anoxic lake that is primarily anoxic during autumn [1,2]. Hongfeng is one of three drinking-water sources for approximately 3 million people in Guiyang, and it is a multi-functional water body that is also used for hydropower, flood control, shipping, recreation and commercial aquaculture (cage-culture fishing). Hongfeng was 
constructed in the 1960s, and it is situated on the Maotiao River, which flows into the Wujiang River, a major tributary of the Yangtze River [3,4]. As a result, the pollution status of Lake Hongfeng has a close relationship with the social development of the Guiyang area as well as ecological systems of the Yangtze River.

When high external nutrient (mainly phosphorus and nitrogen) loads are sustained for a considerable length of time, the ecological balance within a lake changes from a desirable macrophyte-dominated clear-water system to an undesirable turbid system with high nutrient levels and elevated phytoplankton biomass [5]. It is important to understand Liebig's Law or the Law of the Minimum when dealing with plants like algae. The Law states that plant growth will continue as long as all required factors are present (e.g. light, water, nitrogen, phosphorus and potassium). When one of those factors is depleted, growth stops. Increasing the amount of the "limiting" component will allow the growth to continue until that component (or another) is deplepted. Phosphorus often limits primary production in many freshwater ecosystems [6,7]; thus it is regarded as one of the most important limiting factors among nutrients for accelerating eutrophication [8-12]. Contaminants, e.g. phosphorus, nitrogen and heavy metals, in aquatic ecosystems can be evaluated by various media, such as water, biota, suspended materials, and sediments [13]. Sediments can act as a source or a sink in the exchange of phosphorus between overlying water and suspended particles. Specifically, the sediment can act as a source, releasing phosphorus into the water body to satisfy the growth of phytoplankton $[14,15]$. Conversely, when nutrients in the water body are oversupplied, phytoplankton can bloom, increasing the organic matter content. Under such conditions, the sediment becomes a sink $[16,17]$. Accordingly, phosphorus in the sediment has a vital role in aquatic ecosystems. Based on sequential extraction techniques, phosphorus in sediments is commonly divided into organic and inorganic forms and the inorganic forms are further divided into dissolved phosphorus (DP), aluminum-bound phosphorus (Al-P), iron-bound phosphorus $(\mathrm{Fe}-\mathrm{P})$ and calcium-bound phosphorus $(\mathrm{Ca}-\mathrm{P})$ [18-21]. This partition of phosphorus species in sediments is important because it is based on the diversity of phosphorus bioavailability and release potential in different lake environments.

Lake Hongfeng receives large quantities of phosphorus from various sources, and phosphorus has been the limiting factor leading to eutrophication in the lake [3], which has sometimes caused algal blooms, fish suffocation, taste-andodor problems for water suppliers and other undesirable effects [22]. Some algae can produce toxins that are associated with human health problems [23]. Thus, the analysis of phosphorus in sediments from the lake is critical. Eutrophication of the lake has resulted in concern among local governments and environmental researchers, and several studies investigating the chemical species of phosphorus in the sediments based on sequential extraction techniques have already been conducted [24-26]. However, to the best of our knowledge, there have been no studies in China in this field that have employed X-ray powder diffraction (XRD), which is a non-destructive and rapid analytical technique primarily used for phase identification of crystalline materials that can provide information regarding unit cell dimensions. In this study, the techniques of sequential extraction [18] were used in conjunction with XRD to study phosphorus species in the sediments from Lake Hongfeng. The primary objectives were to study the distribution characteristics of phosphorus and its species in sediments from the lake and to analyze the correlations between the phosphorus forms to identify possible origins of the phosphorus loadings and transformation mechanism of the phosphorus species, and finally, to provide useful data for comprehensive restoration of the lake. In addition, possible remediation measures were evaluated for the lake while considering the karstic environment.

\section{Materials and methods}

\subsection{Sampling}

Superficial sediment samples analyzed in this study were collected during September 2009 from Lake Hongfeng using a stainless steel grab-sampler at the following locations: Matou, Daba, Jinmengyuan, Daposhang, Beihuhuxin, Tixiao, Huayudong, Huayudongdaqiao, Aoli, Houwu, Xinzhuang, Laohouwu and Houwuhuodianchang. These sampling locations were selected based on the size, shape, direction of water flow in the lake, and the possible origins of pollutants (Figure 1). The precise collection sites were located in situ using a global positioning system (GPS). Each sediment sample was obtained by mixing three to four sediments collected near the sampling location. Samples were collected in glass bottles $\left(1000 \mathrm{~cm}^{3}\right.$ volume) that had been pre-cleaned with $5 \% \mathrm{HCl}(\mathrm{v} / \mathrm{v})$ and $5 \% \mathrm{HNO}_{3}(\mathrm{v} / \mathrm{v})$ and immediately transported to the laboratory, where they were centrifuged, after which the supernatant was discarded. Subsamples of the sediments were dried at room temperature for 1-2 weeks prior to the experiments, after which they were ground into powders and passed through a nylon sieve, and the $<150 \mu \mathrm{m}$ fraction was collected for analysis. The sediment powder was oven-dried at $105^{\circ} \mathrm{C}$ for $24 \mathrm{~h}$ to determine the moisture content [27].

\subsection{Instruments and reagents}

The following instruments were used in this study: A GPS-72 from American Garmin Corporation (Taiwan, China), an UV-Visible spectrophotometer (Cary 100 Bio) produced by Varian Corporation (USA), an X-ray diffractometer (X'pert PRO) produced by PANalytical Corporation (Holland), a water purification system (Nex Power 2000) 

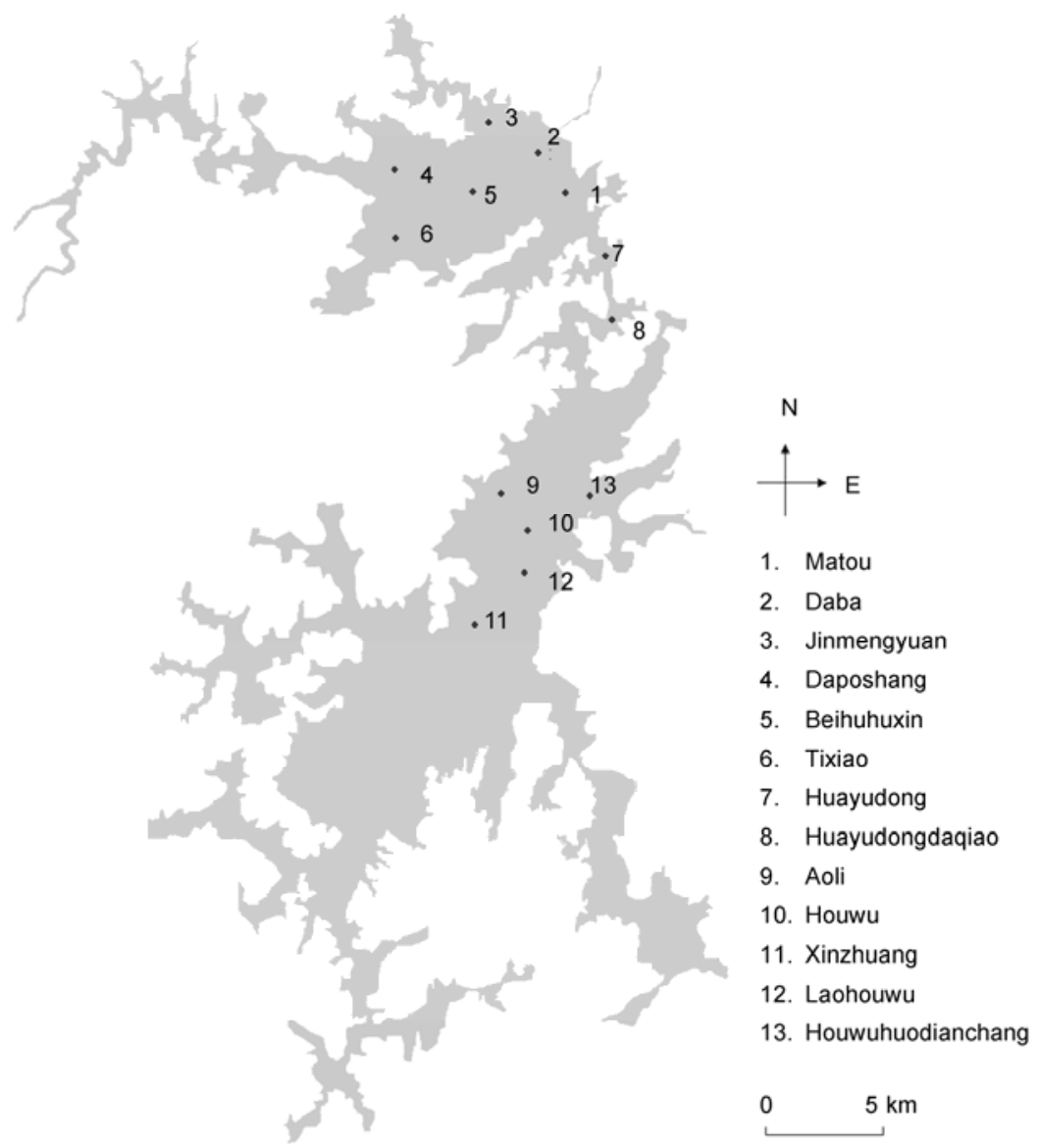

Figure 1 Distribution of sampling sites in Lake Hongfeng.

produced by Human Corporation (Korea) and an immersion oscillator (SHZ-C) from Shanghai Medical Instruments Corporation (China). All reagents used in this study were made in China. Hydrochloric acid $(\mathrm{HCl})$, nitric acid $\left(\mathrm{HNO}_{3}\right)$ and sulfuric acid $\left(\mathrm{H}_{2} \mathrm{SO}_{4}\right)$ were of a guaranteed reagent grade, and the other reagents used were of an analytical reagent grade. Deionized water was prepared using the water purification system listed above.

\subsection{Analysis of TP in sediments from the lake}

The analytical method for TP determination from a SMT protocol developed by the Standard Measurements and Testing Program of the European Commission was applied in this study [28]. Briefly, $0.1000 \mathrm{~g}$ of each sediment sample (dried at room temperature) was accurately weighed into a crucible and calcined at $450^{\circ} \mathrm{C}$ for $3 \mathrm{~h}$. Next, $20 \mathrm{~mL}$ of 3.5 $\mathrm{mol} / \mathrm{L} \mathrm{HCl}$ was added to the sample, which was then shaken on the oscillator mentioned above at $30 \mathrm{r} / \mathrm{min}$ and $25^{\circ} \mathrm{C}$ for $16 \mathrm{~h}$. The extract was then separated from the solid residue by centrifugation at $4000 \times g$ for $15 \mathrm{~min}$. Next, the supernatant was decanted and collected for analysis, after which the residue was discarded. A blank was prepared and replicate samples were analyzed at the same time. The phosphorus concentrations were determined using a spectropho- tometric technique based on the formation of heteropoly species of phosphoric acid with ammonium molybdate. For quality assurance of the TP determination, a soil sample obtained from China's National Reference Materials (Sample Code: GBW 07403) was analyzed. The analytical result of the reference material in this study was consistent with the certified value (Table 1). Analysis of the spatial distribution of phosphorus pollution in the sediments was conducted using the ArcGIS software.

\subsection{Investigation of chemical speciation of phosphorus in sediments from the lake by sequential extraction}

The following sequential extraction procedure designed to target phosphorus forms was employed in this study [18]. First step (DP): $1.0000 \mathrm{~g}$ of each sediment sample was weighed accurately into a $100-\mathrm{mL}$ centrifuge tube, after which $50 \mathrm{~mL}$ of $1 \mathrm{~mol} / \mathrm{L} \mathrm{NH}_{4} \mathrm{Cl}$ solution was added. The mixture was then shaken on the oscillator at $30 \mathrm{r} / \mathrm{min}$ and $25^{\circ} \mathrm{C}$ for $30 \mathrm{~min}$. Next, the extract was separated from the solid residue by centrifugation at $4000 \times g$ for $15 \mathrm{~min}$. The supernatant was then decanted and collected for analysis and the residue was reserved for the next step of analysis. Second step (Al-P): $50 \mathrm{~mL}$ of $0.5 \mathrm{~mol} / \mathrm{L} \mathrm{NH}_{4} \mathrm{~F}$ solution was added to the residue from the first step and the $\mathrm{pH}$ value 
Table 1 TP concentrations in sediments from Lake Hongfeng (dry weight) and the certified and detected TP concentrations of the standard reference material (GBW-07403)

\begin{tabular}{lc}
\hline \multicolumn{1}{c}{ Sampling sites } & $\mathrm{TP}(\mathrm{mg} / \mathrm{kg})$ \\
\hline 1. Matou & 1988.56 \\
2. Daba & 1293.64 \\
3. Jinmengyuan & 1964.49 \\
4. Daposhang & 1464.95 \\
5. Beihuhuxin & 1783.82 \\
6. Tixiao & 973.36 \\
7. Huayudong & 1536.43 \\
8. Huayudongdaqiao & 1626.27 \\
9. Aoli & 1792.50 \\
10. Houwu & 1249.97 \\
11. Xinzhuang & 2334.18 \\
12. Laohouwu & 1935.76 \\
13. Houwuhuodianchang & 1322.44 \\
Mean & 1635.88 \\
GBW-07403 & $320 \pm 18$ \\
\hline
\end{tabular}

was adjusted to 7.0. The mixture was shaken on the oscillator at $30 \mathrm{r} / \mathrm{min}$ and $25^{\circ} \mathrm{C}$ for $1 \mathrm{~h}$. The extract was then separated as before, and the residue was reserved for the next step of analysis. Third step (Fe-P): $50 \mathrm{~mL}$ of $0.1 \mathrm{~mol} / \mathrm{L}$ $\mathrm{NaOH}$ solution was added to the residue from the second step and the mixture was subsequently shaken on the oscillator at $30 \mathrm{r} / \mathrm{min}$ and $25^{\circ} \mathrm{C}$ for $17 \mathrm{~h}$. The extract was then separated as above and the residue was reserved for the next step of analysis. Fourth step (Ca-P): $50 \mathrm{~mL}$ of $0.5 \mathrm{~mol} / \mathrm{L}$ $\mathrm{H}_{2} \mathrm{SO}_{4}$ solution was added to the residue from the third step, after which the mixture was shaken on the oscillator at 30 $\mathrm{r} / \mathrm{min}$ at $25^{\circ} \mathrm{C}$ for $1 \mathrm{~h}$. The extract was then separated as in the previous steps, and the residue was discarded. For inorganic phosphorus (IP) determination, $0.1000 \mathrm{~g}$ of each sediment sample was weighed accurately into a $100-\mathrm{mL}$ centrifuge tube, after which $20 \mathrm{~mL}$ of $1 \mathrm{~mol} / \mathrm{L} \mathrm{HC} 1$ solution was added. The mixture was then shaken on the oscillator mentioned above at $30 \mathrm{r} / \mathrm{min}$ at $25^{\circ} \mathrm{C}$ for $16 \mathrm{~h}$. The extract was subsequently separated from the solid residue by centrifugation at $4000 \times g$ for $15 \mathrm{~min}$. The supernatant was then decanted and collected for analysis, and the residue was discarded. The OP was calculated from the difference between TP and IP. The phosphorus concentrations of all extracts were determined as for TP using the method described above. To determine the phosphorus forms, the sum of percentages of each phosphorus species was compared with that of the TP in each sediment sample to verify the accuracy due to the lack of suitable standard reference material. As shown in Table 2, the sum of percentages ranged from $92.06 \%$ to $99.94 \%$. For each set of analyses, blanks were also used for background correction. Up to $15 \%$ of the samples were replicated to control the analytical quality, and the relative standard deviations were less than $5 \%$.

\subsection{Study of phosphorus forms in sediments from the lake by XRD}

XRD analysis was conducted directly on the air-dried sediment samples described above. Briefly, dried powders of each sediment sample were pressed into a 1.3 -cm-diameter sample plexiglass holder well with a thickness of $1 \mathrm{~mm}$. The XRD analysis adopted a multifunctional sample stage MPSS (vertical system). Specifically, the scan speed was $32 \% \mathrm{~min}$, the tension was $40 \mathrm{kV}$, the current was $40 \mathrm{~mA}$, and the step size was $0.0167^{\circ}$. The original data were rectified using the Jade program to eliminate $\mathrm{K} \alpha$ and then obtain the XRD pattern for a sample. The major compositions of sediments from Lake Hongfeng were obtained in conjunction with the database.

Table 2 Phosphorus speciation in sediments from Lake Hongfeng (dry weight)

\begin{tabular}{|c|c|c|c|c|c|c|c|c|c|c|c|}
\hline \multirow{2}{*}{$\begin{array}{l}\text { Sample } \\
\text { number }\end{array}$} & \multicolumn{2}{|c|}{ DP } & \multicolumn{2}{|c|}{$\mathrm{Al}-\mathrm{P}$} & \multicolumn{2}{|c|}{$\mathrm{Fe}-\mathrm{P}$} & \multicolumn{2}{|c|}{$\mathrm{Ca}-\mathrm{P}$} & \multicolumn{2}{|c|}{ OP } & \multirow{2}{*}{$\frac{\text { Sum }}{(\%)}$} \\
\hline & $(\mathrm{mg} / \mathrm{kg})$ & $(\%)$ & $(\mathrm{mg} / \mathrm{kg})$ & $(\%)$ & $(\mathrm{mg} / \mathrm{kg})$ & $(\%)$ & $(\mathrm{mg} / \mathrm{kg})$ & $(\%)$ & $(\mathrm{mg} / \mathrm{kg})$ & $(\%)$ & \\
\hline 1 & 6.88 & 0.35 & 145.85 & 7.33 & 103.78 & 5.22 & 874.92 & 44.00 & 855.96 & 43.04 & 99.94 \\
\hline 2 & 1.07 & 0.08 & 56.90 & 4.40 & 245.65 & 18.99 & 274.27 & 21.20 & 613.03 & 47.39 & 92.06 \\
\hline 3 & 7.88 & 0.40 & 188.66 & 9.60 & 50.89 & 2.59 & 865.08 & 44.04 & 826.75 & 42.08 & 98.71 \\
\hline 4 & 3.24 & 0.22 & 117.06 & 7.99 & 90.51 & 6.18 & 622.39 & 42.49 & 590.61 & 40.32 & 97.20 \\
\hline 5 & 5.98 & 0.34 & 166.49 & 9.33 & 74.26 & 4.16 & 855.92 & 47.98 & 661.24 & 37.07 & 98.88 \\
\hline 6 & 1.07 & 0.11 & 62.83 & 6.45 & 51.51 & 5.29 & 369.65 & 37.98 & 450.54 & 46.29 & 96.12 \\
\hline 7 & 9.03 & 0.59 & 121.68 & 7.92 & 25.81 & 1.68 & 791.93 & 51.54 & 492.43 & 32.05 & 93.78 \\
\hline 8 & 8.63 & 0.53 & 103.01 & 6.33 & 49.65 & 3.05 & 774.24 & 47.61 & 574.10 & 35.30 & 92.82 \\
\hline 9 & 7.00 & 0.39 & 89.85 & 5.01 & 62.50 & 3.49 & 789.20 & 44.03 & 766.97 & 42.79 & 95.71 \\
\hline 10 & 7.11 & 0.57 & 58.95 & 4.72 & 14.76 & 1.18 & 623.60 & 49.89 & 489.19 & 39.14 & 95.50 \\
\hline 11 & 13.89 & 0.60 & 154.49 & 6.62 & 89.55 & 3.84 & 1394.86 & 59.76 & 615.82 & 26.38 & 97.20 \\
\hline 12 & 8.12 & 0.42 & 191.34 & 9.88 & 159.28 & 8.23 & 1005.13 & 51.92 & 561.56 & 29.01 & 99.46 \\
\hline 13 & 8.37 & 0.63 & 81.19 & 6.14 & 25.94 & 1.96 & 644.98 & 48.77 & 522.13 & 39.48 & 96.98 \\
\hline Mean & 6.79 & 0.40 & 118.33 & 7.06 & 80.31 & 5.07 & 760.47 & 45.48 & 616.95 & 38.49 & 96.49 \\
\hline
\end{tabular}




\section{Results and discussion}

\subsection{Distribution of TP in sediments in the lake}

The TP concentrations in the sediments ranged from 973.36 to $2334.18 \mathrm{mg} / \mathrm{kg}$ (Table 1), and the average value was $1635.88 \mathrm{mg} / \mathrm{kg}$ (dry weight). It has been reported that the TP in sediments from Lake Chaohu in Anhui Province and Lake Xihu in Fujian Province, China, ranged from 450 to $560 \mathrm{mg} / \mathrm{kg}$ and from 750 to $900 \mathrm{mg} / \mathrm{kg}$, respectively $[29,30]$. Therefore, these findings indicate that the phosphorus level in sediments from Lake Hongfeng was high compared with those from Lake Chaohu and Lake Xihu, which are both eutrophic lakes. This was likely due to the local geology, which is rich in phosphate rock deposits, as well as phosphorus inputs into the lake with the development of industrial and commercial activities in the watershed during the past two decades. The pollution sources of different industrial effluents include coal-fired power plants and chemical industries (e.g. fertilizer plants) located near Qingzhen and along the Yangchang River, which is the main headstream of Lake Hongfeng. The sewage treatment facilities for these pollution sources have not been effective and the effluents discharged into the lake from the facilities have not met effluent standards. The other pollutants originate from urban activities (e.g. use of detergents), agriculture, cage-culture fishing, recreation, coal mining, storm water runoff and atmospheric deposits. It should be noted that cage-culture fishing was popular in the lake during the 1990s. As a result, this activity likely had a considerable effect on the nutrient (e.g. OP) loadings in the lake, despite being recently prohibited. Based on its geographical surroundings, it was obvious that the primary sources of phosphorus to Lake Hongfeng were fertilizer plants and rural and urban activities from Pingba County [3]. The spatial analysis using the geographic information system (GIS) was applied to combine geostatistics with the phosphorus pollution in sediments from Hongfeng. This not only provides an understanding of the spatial distribution characteristics of phosphorus concentrations in the sediments, but can also help reveal the status of phosphorus pollution in the sediments. Therefore, in this study, the Kriging interpolation calculation was conducted for the spatial distribution of phosphorus pollution in the sediments using the ArcGIS software (Figure 2).

The highest TP was observed at the Xinzhuang sampling site, followed by the Matou sampling site, and these two values were much higher than those of the other sites. The lowest TP value was observed at the Tixiao site. This was likely due to the distribution of point pollution sources around the lake. The primary pollution sources around the Xinzhuang site were likely to be urban sewage from Pingba County and wastewater from some fertilizer producing companies, especially the Pingba Fertilizer Plant, which primarily produces phosphorus-related products. Although the Pingba Fertilizer Plant is no longer in operation, its effects on phosphorus loadings in the lake are still likely to be considerable. The primary pollution sources for the Matou site are urban sewage from Qingzhen and industrial wastewater from the nearby Guizhou Fertilizer Plant. However, point source pollution was lower around the Tixiao site than the other sites.

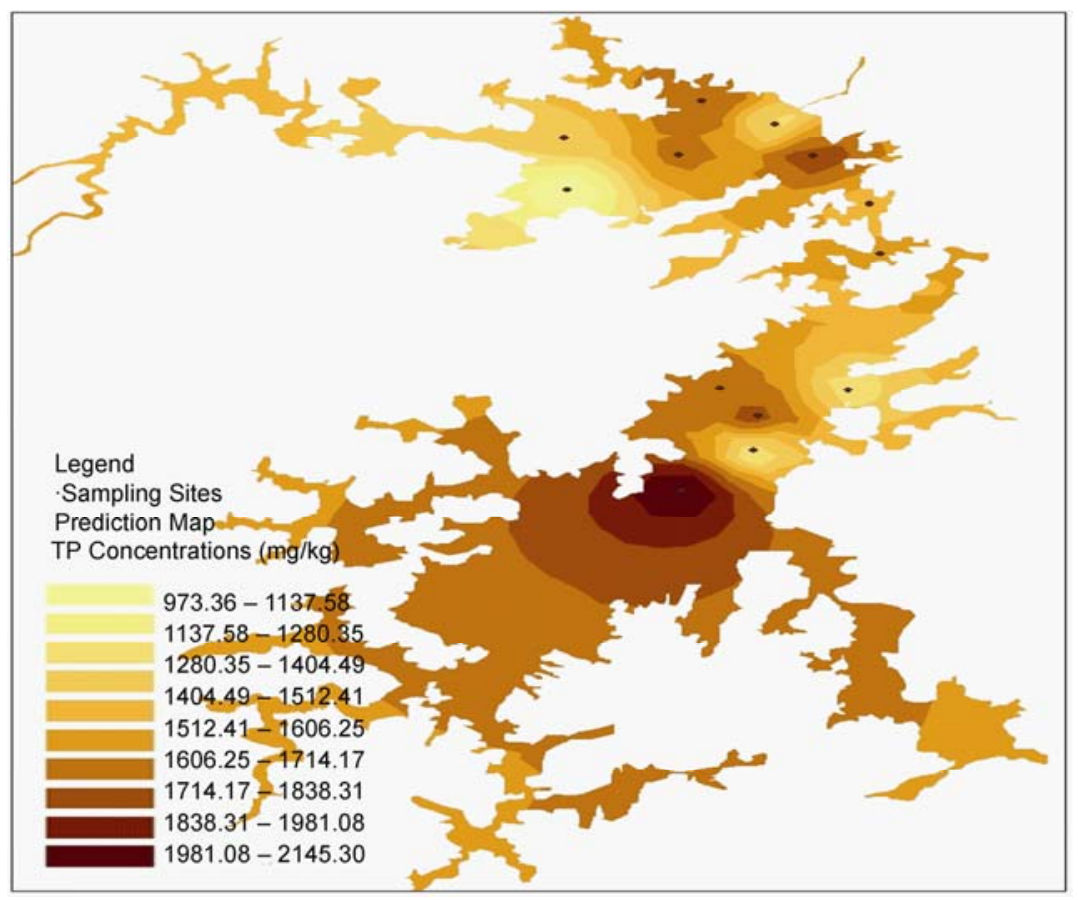

Figure 2 Spatial distribution of phosphorus pollution in sediments from Lake Hongfeng. 


\subsection{Determination of phosphorus forms in sediments from the lake using sequential extraction techniques}

As shown in Table 2 and Figure 3, the average percentages of DP, Al-P, Fe-P, Ca-P and OP in sediments from Lake Hongfeng were $0.40 \%, 7.06 \%, 5.07 \%, 45.48 \%$ and $38.49 \%$, respectively. The results obtained in this study agreed well with some available semiquantitative characteristics in the pertinent literature. These findings suggest that the content of OP in sediments is lower than that of IP, which primarily consists of $\mathrm{Ca}-\mathrm{P}$ (apatitic phosphorus) in sediments from calcareous regions [19]. This is probably due to the typical carbonate-rock dissolution environment of the lake, where there is abundant calcium because deposition of phosphorus is limited by the binding capacity of the sediment [31]. Phosphorus in water is integrated into particles by biological absorption (primary production), chemical transfer (adsorption and sedimentation) and other processes, and the particles sink continually. Mineralization of phosphorus occurs to different degrees following deposition. In general, mineralization mainly occurs at the surface sediment. Both OP and IP in sediments may be transferred to each other and released into the overlying water during mineralization, which results in considerable changes in the phosphorus distributions [16]. Moreover, trivalent iron $\left(\mathrm{Fe}^{3+}\right)$ can adsorb phosphatic ions $\left(\mathrm{PO}_{4}{ }^{3-}\right)$ and be deposited in sediments with $\mathrm{Fe}-\mathrm{P}$. When the buried sediments descend below the redox interface, the depositional environment gradually becomes anoxic and $\mathrm{Fe}^{3+}$ is reduced into bivalent iron $\left(\mathrm{Fe}^{2+}\right)$. Part of the iron is then transferred from sediments into interstitial water because of the higher solubility of $\mathrm{Fe}^{2+}$. Ultimately, these alterations result in decreased accumulative quantities of $\mathrm{Fe}-\mathrm{P}$ in sediments and some sedimentary phosphorus with species of $\mathrm{Fe}-\mathrm{P}$ being released from sediments into the overlying water [32]. Lake Hongfeng is a seasonal anoxic lake. It is generally accepted that in a reductive environment, $\mathrm{Fe}^{3+}$ is easily reduced to $\mathrm{Fe}^{2+}$, which causes the release of $\mathrm{Fe}-\mathrm{P}$ to the overlying water [33]. It should be noted that $\mathrm{Ca}-\mathrm{P}$ is a relatively stable, inert and non-bioavailable phosphorus fraction that may temporarily control the release of phosphorus from sediments. This is because there may be a large number of phosphate solubilizing bacteria that can transform insoluble phosphate into bio-available forms. Furthermore, the TP in sediments from the lake was high, which is consistent with the results reported by Jiang et al.[4], who found that the release potential and bioavailability of phosphorus in sediments of this lake were still highly significant.

The results of this study demonstrated that DP was a minor fraction in TP, which consisted primarily of Al-P, Fe-P, $\mathrm{Ca}-\mathrm{P}$ and $\mathrm{OP}$. DP was regarded as readily available for uptake by biota, while $\mathrm{Al}-\mathrm{P}$ and $\mathrm{Fe}-\mathrm{P}$, which were considered to be primarily from industrial wastewater and urban sewage discharges, were also bio-available fractions of phosphorus in the absence of oxygen. $\mathrm{Ca}-\mathrm{P}$ was considered to be related to the local geology, while OP was considered to be primarily from rural agricultural cultivation and fertilization and was a steady, but continuously bio-available fraction of phosphorus. Thus, according to the analysis of phosphorus fractions in sediments, the primary sources of pollution can be assessed and various restoration measures can be adopted for different regions. OP is an important component of lake sediments that can be transferred into bio-available nutrients by enzymatic hydrolysis and microbial activity. This behavior has an important role in lake ecosystems [34]. In Lake Hongfeng, the highest value of OP was observed at the Matou sampling site, followed by the Jinmengyuan site, and the values observed at these sites were much higher than those observed at other sites. The OP levels were lowest at the Tixiao site. The Matou and Jinmengyuan sites are close to the Guizhou Fertilizer Plant and Qingzhen, respectively; thus these sites were heavily influenced by industrial wastewater and urban sewage. Conversely, no industrial wastewater or urban sewage directly influences the Tixiao site.

For further study, correlations between phosphorus and its species in sediments from Lake Hongfeng were analyzed.

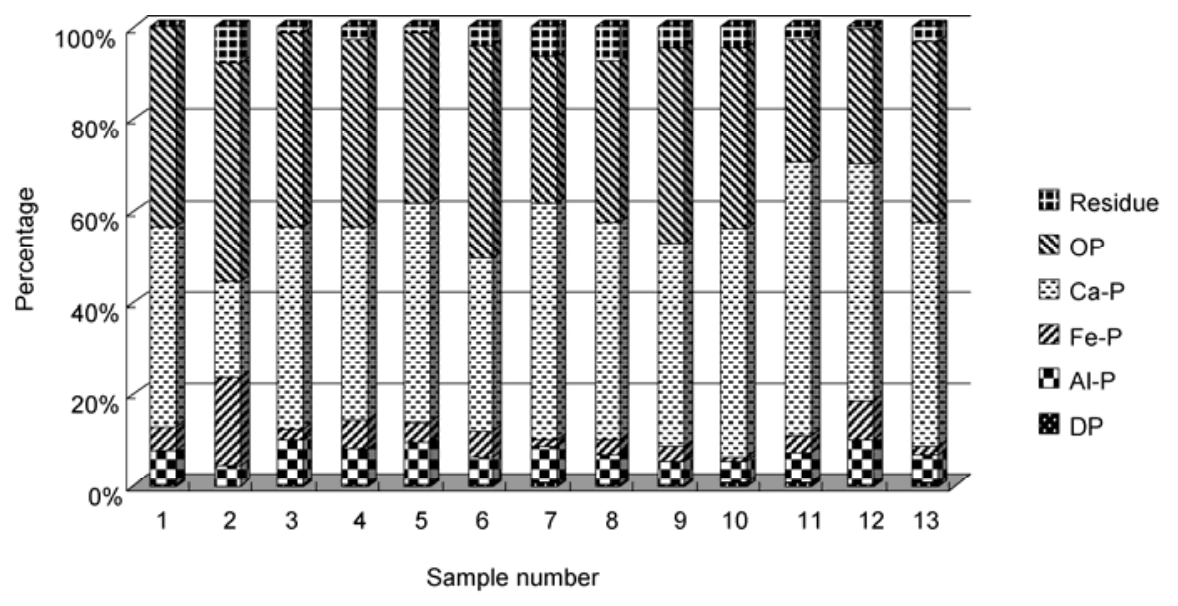

Figure 3 Percentage of phosphorus species in sediments from Lake Hongfeng. 
As shown in Table 3, the results of correlation analysis indicated that there was no apparent correlation between the concentrations of $\mathrm{Fe}-\mathrm{P}$ and $\mathrm{TP}$ in the sediments. This was likely caused by the fact that $\mathrm{Fe}-\mathrm{P}$ has been identified as a potential variable component in sedimentary phosphorus. However, DP, Al-P, OP, and Ca-P all showed significant positive correlations with TP. This indicated that the TP in the sediments was closely related to its speciation, and that the chemical forms of phosphorus in the sediments may be utilized as a potential marker to assess the phosphorus pollution level. These results also suggested that apatitic phosphorus was the most important fraction of IP in the sediments from calcareous regions as presented above. A strong positive correlation between the concentrations of DP and $\mathrm{Ca}-\mathrm{P}$ in the sediments was also observed, and Al-P exhibited a significant positive correlation with $\mathrm{Ca}-\mathrm{P}$, indicating that $\mathrm{Ca}-\mathrm{P}$ has an important role in the biogeochemical process of phosphorus. This may be attributed to the bio-available fraction of phosphorus, since DP and Al-P were both readily bio-available phosphorus fractions. Although $\mathrm{Ca}-\mathrm{P}$ was a relatively stable, inert and non-bioavailable phosphorus fraction, there may be a large number of phosphate solubilizing bacteria that can transform insoluble phosphate into the bio-available forms mentioned above.

To present an in-depth analysis of the correlations between phosphorus and its species, Bartlett's test of sphericity (BTS) was conducted followed by principal component analysis (PCA). BTS is used to test the null hypothesis that the variables in a population correlation matrix are uncorrelated. The significance level observed upon BTS was 0.000 , which was small enough to reject the hypothesis, indicating that the strength of the relationship among variables was strong. In addition, the results of Pearson's correlation analysis revealed some correlations between phosphorus species. Therefore, this dataset was appropriate for PCA. The PCA results (Table 4, only loading scores greater than 0.5 were considered) demonstrated that there were two principal components that could explain $82.6 \%$ of the total variance. As shown in Table 4, component 1 accounted for $59.0 \%$ of the total variance and consisted of TP, DP, Al-P, $\mathrm{Ca}-\mathrm{P}$ and OP. Component 2 accounted for $23.6 \%$ of the total variance and $\mathrm{OP}$, especially $\mathrm{Fe}-\mathrm{P}$, comprised a majority

Table 3 Pearson's correlation coefficients between TP, DP, Al-P, Fe-P, $\mathrm{Ca}-\mathrm{P}$ and $\mathrm{OP}$ in sediments from Lake Hongfeng

\begin{tabular}{cllllll}
\hline & \multicolumn{1}{c}{ TP } & DP & Al-P & Fe-P & Ca-P & OP \\
\hline TP & 1 & & & & & \\
DP & $0.715^{\text {a) }}$ & 1 & & & & \\
Al-P & $0.810^{\text {a) }}$ & 0.486 & 1 & & & \\
Fe-P & 0.119 & -0.368 & 0.070 & 1 & & \\
Ca-P & $0.907^{\text {a) }}$ & $0.886^{\text {a) }}$ & $0.742^{\text {a) }}$ & -0.160 & 1 & 1 \\
OP & $0.642^{\text {b) }}$ & 0.128 & 0.485 & 0.181 & 0.319 & 1 \\
\hline
\end{tabular}

a) Correlation is significant at the 0.01 level (two-tailed). b) Correlation is significant at the 0.05 level (two-tailed).
Table 4 Component matrix

\begin{tabular}{ccc}
\hline & \multicolumn{2}{c}{ Principal components } \\
\cline { 2 - 3 } & Component $1\left(59.0 \%^{\mathrm{a})}\right)$ & Component 2 $\left(23.6 \%^{\mathrm{a})}\right)$ \\
\hline TP & 0.975 & - \\
DP & 0.805 & - \\
Al-P & 0.848 & - \\
Fe-P & - & 0.855 \\
Ca-P & 0.951 & - \\
OP & 0.563 & 0.565 \\
\hline
\end{tabular}

a) Percentage of variance.

of this component. Based on these findings, component 1 may be seen as stressing the origins of phosphorus loadings from both terrigenous and external inflows (point and non-point pollution sources), e.g. the geochemical features in this region, industrial wastewater, and urban sewage from nearby towns and villages. Component 2 is likely to be primarily associated with the depositional environment of the sediments (e.g. redox conditions). Fe-P content can reflect the complexity of the depositional environment in sediments as presented above [32]. In addition, mineralization of OP can be catalyzed by alkaline phosphatase [35], after which OP is transferred into the soluble orthophosphate pool, which may be removed from the dissolved phase by chemical precipitation with $\mathrm{Al}^{3+}, \mathrm{Fe}^{3+}$ and $\mathrm{Ca}^{2+}$, and subsequently undergo diagenesis, which relates to the local redox conditions [19]. Moreover, $\mathrm{Fe}-\mathrm{P}$ in the sediments can probably be explained by the fact that one of the primary pollutant sources for Lake Hongfeng is a nearby coal mining that discharged a large amount of Fe-containing wastewater. Obviously, knowledge of the different forms of phosphorus present in the sediments is useful.

Hierarchical cluster analysis (HCA) was also conducted. HCA is a statistical method for identifying relatively homogeneous clusters of cases based on measured characteristics. In HCA, each case is initially in a separate cluster, and the clusters are then combined sequentially, reducing the number of clusters at each step until only one is left. The dendrogram produced by HCA in the present study describing the phosphorus and its species in sediments from Hongfeng is shown in Figure 4. In the dendrogram, the horizontal scale corresponds to the degrees of pollution at the various locations. In general, the four-cluster level was selected for all test locations. The first cluster contains six locations, Houwu, Houwuhuodianchang, Huayudong, Huayudongdaqiao, Daposhang and Tixiao, while the second cluster contains four locations, Matou, Jinmengyuan, Beihuhuxin and Aoli, the third cluster contains two locations, Xinzhuang and Laohouwu and the fourth cluster contains only one location, Daba. Clearly, the pollution statuses of all locations belonging to a cluster are similar, with a greater distance among clusters indicating a greater discrepancy in the pollution intensity in the sediments. 
Dendrogram using average linkage (between groups)

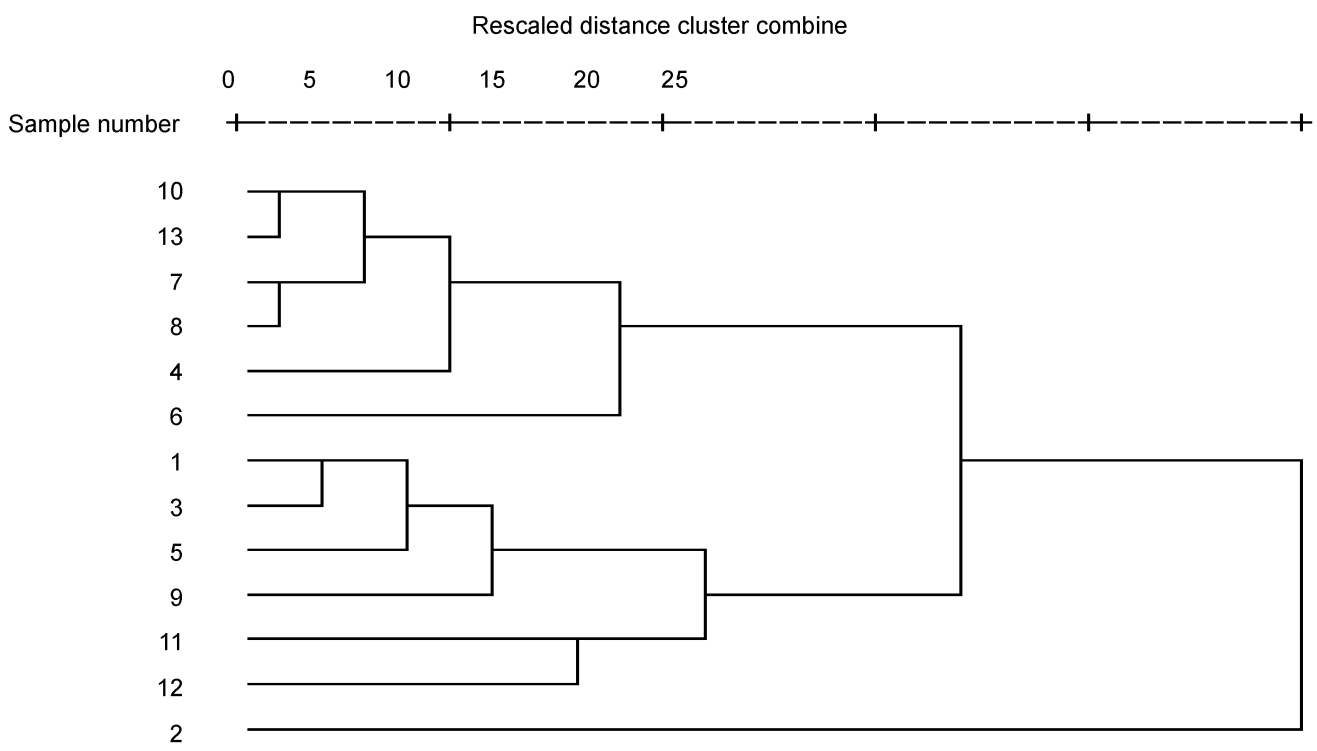

Figure 4 Dendrogram plot of HCA for phosphorus and its species in sediments from Lake Hongfeng.

\subsection{Determination of phosphorus species in sediments from the lake using XRD}

XRD was used to determine the mineralogy of crystalline phases of all samples for which there was adequate crystalline sediment for analysis. The results of XRD analysis showed that the major compositions of all sediment samples from Hongfeng included $\mathrm{SiO}_{2}$ and $\mathrm{CaCO}_{3}$ (Table 5). $\mathrm{AlPO}_{4}$ was found in all sediment samples according to the relative semiquantification (Table 6). In addition, there were other compounds containing phosphorus in the sediments, including $\mathrm{Bi}_{0.5} \mathrm{Sb}_{1.5}\left(\mathrm{PO}_{4}\right)_{3}, \mathrm{CrPO}_{4},(\mathrm{~K}, \mathrm{Na})_{2} \mathrm{Mg}\left(\mathrm{P}_{2} \mathrm{O}_{7}\right),(\mathrm{Zn}, \mathrm{Ca})$ $\mathrm{Al}_{2} \mathrm{P}_{2} \mathrm{H}_{6} \mathrm{O}_{12} \cdot 3 \mathrm{H}_{2} \mathrm{O}, \mathrm{BiSb}_{3}\left(\mathrm{PO}_{4}\right)_{6}, \mathrm{Cr}\left(\mathrm{NH}_{4}\right) \mathrm{HP}_{3} \mathrm{O}_{10}, \mathrm{C}_{6} \mathrm{H}_{10} \mathrm{O}_{10} \mathrm{P}_{2} \mathrm{Sn}$, $\mathrm{LiMgPO}_{4}, \mathrm{KNaCa}_{2}\left(\mathrm{PO}_{4}\right)_{2}, \mathrm{Hf}\left(\mathrm{HPO}_{4}\right)_{2}, \mathrm{Ti}_{0.33} \mathrm{Zr}_{0.67}\left(\mathrm{HPO}_{4}\right)_{2} \cdot \mathrm{H}_{2} \mathrm{O}$, $\mathrm{NaCrP}_{2} \mathrm{O}_{7}, \mathrm{CoPS}, \mathrm{NbPO}_{5}, \mathrm{Na}_{3} \mathrm{PO}_{4}, \mathrm{Na}_{3} \mathrm{PSO}_{3} \cdot 9 \mathrm{H}_{2} \mathrm{O}, \mathrm{H}_{3} \mathrm{PW}_{12}-$ $\mathrm{O}_{40} \cdot 29 \mathrm{H}_{2} \mathrm{O}, \mathrm{KSb}_{2} \mathrm{PO}_{8}, \mathrm{C}_{3} \mathrm{H}_{10} \mathrm{O}_{5} \mathrm{P}_{2}, \mathrm{C}_{3} \mathrm{H}_{10} \mathrm{O}_{6} \mathrm{P}_{2}, \mathrm{C}_{2} \mathrm{H}_{8} \mathrm{NO}_{4} \mathrm{P}$, $\mathrm{Pb}_{4} \mathrm{BiO}_{4} \mathrm{PO}_{4}, \mathrm{Ba}_{5}\left(\mathrm{PO}_{4}\right)_{3}(\mathrm{OH}), \mathrm{NaCrTa}\left(\mathrm{PO}_{4}\right)_{3}, \mathrm{C}_{4} \mathrm{H}_{12} \mathrm{O}_{5} \mathrm{P}_{2}$, $\mathrm{C}_{4} \mathrm{H}_{12} \mathrm{O}_{6} \mathrm{P}_{2}, \quad \mathrm{Zr}\left(\mathrm{HPO}_{4}\right) \cdot \mathrm{H}_{2} \mathrm{O}, \quad \mathrm{LiMnPO}_{4}, \quad \mathrm{Rb}_{3} \mathrm{Nd}\left(\mathrm{PO}_{4}\right)_{2}$, $\mathrm{CdZn}_{3}\left(\mathrm{P}_{2} \mathrm{O}_{7}\right)_{2}, \mathrm{GaPO}_{4}, \mathrm{YbPtP}, \mathrm{PtSi}_{2} \mathrm{P}_{2}, \mathrm{Srlr}_{2} \mathrm{P}_{2}, \mathrm{PbHPO}_{4}$, $\left(\mathrm{Br}_{3} \mathrm{P}(\mathrm{OH})\right)\left(\mathrm{AsF}_{6}\right), \mathrm{Ba}_{10}\left(\mathrm{PO}_{4}\right)_{6} \mathrm{~S}, \mathrm{LuPtP}, \mathrm{Pb}_{0.66}\left(\mathrm{PO}_{2}\right)_{4}\left(\mathrm{WO}_{3}\right)_{14}$, $\mathrm{Cs}_{3} \mathrm{P}_{11}, \mathrm{Cs}_{3} \mathrm{P}_{11.6}, \mathrm{Cs}_{3} \mathrm{P}_{11.68}, \mathrm{Ni}_{4} \mathrm{Ge}_{0.33} \mathrm{P}_{1.17}, \mathrm{BaCr}\left(\mathrm{P}_{2} \mathrm{O}_{7}\right)$ and $\mathrm{Ag}_{3} \mathrm{PO}_{4}$. Based on our XRD analysis, it was difficult to assign a specific mineral composition to samples with sparse sediment. In these samples, individual particles were indistinguishable, or there were only a few small particles with a distinct morphology on which to base the determination. Nevertheless, the results of XRD analysis further demonstrated the existence of phosphorus species in sediments from Lake Hongfeng, including DP, Al-P, Fe-P, Ca-P and $\mathrm{OP}$, which confirmed the results of the sequential extraction. These findings indicate that there is a significant risk of phosphorus release from the sediments because the risk of the release of DP, Al-P and Fe-P is significant, and these compounds are part of the bio-available phosphorus fraction. Moreover, phosphorus has been identified as the limiting factor leading to eutrophication, which has sometimes caused algal blooms [3]. Therefore, the release potential in the sediments of this lake was highly significant.

Additionally, the results of XRD analysis demonstrated that $\mathrm{AlPO}_{4}$ was present in all sediment samples at relatively high concentrations, while $\mathrm{Ca}-\mathrm{P}$ was found only in several sediment samples. It is interesting to note that the results of the sequential extraction and XRD differed since the results of sequential extraction have demonstrated that the concentrations of

Table 5 Major compositions of sediments from Lake Hongfeng

\begin{tabular}{|c|c|}
\hline Sampling sites & Major compositions \\
\hline 1. Matou & $\mathrm{SiO}_{2}, \mathrm{CaCO}_{3}, \mathrm{Ca}_{0.3}(\mathrm{Cr}, \mathrm{Mg})_{2}(\mathrm{Si}, \mathrm{Al})_{4} \mathrm{O}_{10}(\mathrm{OH})_{2} \cdot 4 \mathrm{H}_{2} \mathrm{O}^{\mathrm{a}}$ \\
\hline 2. Daba & $\mathrm{SiO}_{2}, \mathrm{CaCO}_{3}, \mathrm{C}_{15} \mathrm{H}_{11} \mathrm{ClN}_{2} \mathrm{O}_{2}$ \\
\hline 3. Jinmengyuan & $\mathrm{SiO}_{2}, \mathrm{CaCO}_{3}$ \\
\hline 4. Daposhang & $\mathrm{SiO}_{2}, \mathrm{CaCO}_{3}$ \\
\hline 5. Beihuhuxin & $\mathrm{SiO}_{2}, \mathrm{CaCO}_{3}$ \\
\hline 6. Tixiao & $\mathrm{SiO}_{2}, \mathrm{CaCO}_{3}$ \\
\hline 7. Huayudong & $\mathrm{SiO}_{2}, \mathrm{CaCO}_{3}$ \\
\hline 8. Huayudongdaqiao & $\mathrm{SiO}_{2}, \mathrm{CaCO}_{3}, \mathrm{Na}_{0.3} \mathrm{Fe}_{2} \mathrm{Si}_{4} \mathrm{O}_{10}(\mathrm{OH})_{2} \cdot 4 \mathrm{H}_{2} \mathrm{O}$ \\
\hline 9. Aoli & $\mathrm{SiO}_{2}, \mathrm{CaCO}_{3}, \mathrm{Na}_{0.3} \mathrm{Fe}_{2} \mathrm{Si}_{4} \mathrm{O}_{10}(\mathrm{OH})_{2} \cdot 4 \mathrm{H}_{2} \mathrm{O}$ \\
\hline 10. Laohouwu & $\mathrm{SiO}_{2}, \mathrm{CaCO}_{3}, \mathrm{Na}_{0.3} \mathrm{Fe}_{2} \mathrm{Si}_{4} \mathrm{O}_{10}(\mathrm{OH})_{2} \cdot 4 \mathrm{H}_{2} \mathrm{O}$ \\
\hline 11. Xinzhuang & $\mathrm{SiO}_{2}, \mathrm{CaCO}_{3}, \mathrm{C}_{15} \mathrm{H}_{11} \mathrm{ClN}_{2} \mathrm{O}_{2}$ \\
\hline 12. Houwu & $\mathrm{SiO}_{2}, \mathrm{CaCO}_{3}$ \\
\hline $\begin{array}{l}\text { 13. Houwuhuo- } \\
\text { dianchang }\end{array}$ & $\mathrm{SiO}_{2}, \mathrm{CaCO}_{3}, \mathrm{Mn}_{3} \mathrm{Ta}_{2} \mathrm{O}_{8}$ \\
\hline
\end{tabular}

a) The major composition of quartz is $\mathrm{SiO}_{2}$; the major composition of calcite is $\mathrm{CaCO}_{3}$; the major composition of volkonskoite is $\mathrm{Ca}_{0.3}(\mathrm{Cr}, \mathrm{Mg})_{2}$ $(\mathrm{Si}, \mathrm{Al})_{4} \mathrm{O}_{10}(\mathrm{OH})_{2} \cdot 4 \mathrm{H}_{2} \mathrm{O}$; the major composition of nontronite is $\mathrm{Na}_{0.3} \mathrm{Fe}_{2}$ $\mathrm{Si}_{4} \mathrm{O}_{10}(\mathrm{OH})_{2} \cdot 4 \mathrm{H}_{2} \mathrm{O}$. The compositions of the other compounds are unknown. 
Table 6 Relative semiquantification among phosphorus species in sediments from Lake Hongfeng

\begin{tabular}{|c|c|c|c|c|c|}
\hline Sample number & Chemical formula & Semi-quant (\%) & Sample number & Chemical formula & Semi-quant (\%) \\
\hline \multirow[t]{5}{*}{1} & $\mathrm{AlPO}_{4}$ & 49 & \multirow[t]{8}{*}{8} & $\mathrm{AlPO}_{4}$ & 36 \\
\hline & $\mathrm{CsAl}_{3}\left(\mathrm{P}_{3} \mathrm{O}_{10}\right)_{2}$ & 28 & & $\mathrm{CsAl}_{3}\left(\mathrm{P}_{3} \mathrm{O}_{10}\right)_{2}$ & 23 \\
\hline & $\mathrm{Li}\left(\mathrm{Fe}_{0.06} \mathrm{Mn}_{0.94}\right)\left(\mathrm{PO}_{4}\right)$ & 14 & & $\mathrm{Na}_{3} \mathrm{Mn}\left(\mathrm{PO}_{4}\right)\left(\mathrm{CO}_{3}\right)$ & 15 \\
\hline & $\left(\mathrm{Al}_{0.29} \mathrm{Ga}_{0.71}\right)\left(\mathrm{PO}_{4}\right)$ & 7 & & $\mathrm{Li}\left(\mathrm{Fe}_{0.06} \mathrm{Mn}_{0.94}\right)\left(\mathrm{PO}_{4}\right)$ & 10 \\
\hline & $\mathrm{FePO}_{4}$ & 1 & & $\left(\mathrm{Al}_{0.29} \mathrm{Ga}_{0.71}\right)\left(\mathrm{PO}_{4}\right)$ & 5 \\
\hline \multirow[t]{5}{*}{2} & $\mathrm{AlPO}_{4}$ & 53 & & $\mathrm{NaPO}_{3} \mathrm{NH}_{3}$ & 4 \\
\hline & $\mathrm{CaDPO}_{4}\left(\mathrm{D}_{2} \mathrm{O}\right)_{2}$ & 24 & & $\mathrm{NaHPO}_{3} \mathrm{NH}_{2}$ & 4 \\
\hline & $\mathrm{Cd}_{1.25} \mathrm{Ca}_{0.75}\left(\mathrm{P}_{2} \mathrm{O}_{7}\right)$ & 12 & & $\mathrm{FePO}_{4}$ & 2 \\
\hline & $\left(\mathrm{Al}_{0.29} \mathrm{Ga}_{0.71}\right)\left(\mathrm{PO}_{4}\right)$ & 6 & \multirow[t]{8}{*}{9} & $\mathrm{CaDPO}_{4}\left(\mathrm{D}_{2} \mathrm{O}\right)_{2}$ & 34 \\
\hline & $\mathrm{Li}\left(\mathrm{Fe}_{0.06} \mathrm{Mn}_{0.94}\right)\left(\mathrm{PO}_{4}\right)$ & 5 & & $\mathrm{AlPO}_{4}$ & 23 \\
\hline \multirow[t]{4}{*}{3} & $\mathrm{AlPO}_{4}$ & 44 & & $\mathrm{CsAl}_{3}\left(\mathrm{P}_{3} \mathrm{O}_{10}\right)_{2}$ & 17 \\
\hline & $\mathrm{CsAl}_{3}\left(\mathrm{P}_{3} \mathrm{O}_{10}\right)_{2}$ & 34 & & $\left(\mathrm{Li}_{0.918} \mathrm{Fe}_{0.027}\right) \mathrm{Mg}\left(\mathrm{PO}_{4}\right)$ & 12 \\
\hline & $\mathrm{CaDPO}_{4}\left(\mathrm{D}_{2} \mathrm{O}\right)_{2}$ & 20 & & $\mathrm{Li}\left(\mathrm{Fe}_{0.06} \mathrm{Mn}_{0.94}\right)\left(\mathrm{PO}_{4}\right)$ & 7 \\
\hline & $\mathrm{FePO}_{4}$ & 2 & & $\mathrm{NaPO}_{3} \mathrm{NH}_{3}$ & 2 \\
\hline \multirow[t]{11}{*}{4} & $\mathrm{AlPO}_{4}$ & 26 & & $\mathrm{NaHPO}_{3} \mathrm{NH}_{2}$ & 2 \\
\hline & $\mathrm{CsAl}_{3}\left(\mathrm{P}_{3} \mathrm{O}_{10}\right)_{2}$ & 19 & & $\mathrm{FePO}_{4}$ & 2 \\
\hline & $\left(\mathrm{Li}_{0.918} \mathrm{Fe}_{0.027}\right) \mathrm{Mg}\left(\mathrm{PO}_{4}\right)$ & 14 & \multirow[t]{6}{*}{10} & $\mathrm{AlPO}_{4}$ & 46 \\
\hline & $\left(\mathrm{Li}_{0.834} \mathrm{Fe}_{0.055}\right) \mathrm{Mg}\left(\mathrm{PO}_{4}\right)$ & 12 & & $\mathrm{CsAl}_{3}\left(\mathrm{P}_{3} \mathrm{O}_{10}\right)_{2}$ & 33 \\
\hline & $\mathrm{CaDPO}_{4}\left(\mathrm{D}_{2} \mathrm{O}\right)_{2}$ & 8 & & $\mathrm{NaPO}_{3} \mathrm{NH}_{3}$ & 7 \\
\hline & $\mathrm{Li}\left(\mathrm{Fe}_{0.06} \mathrm{Mn}_{0.94}\right)\left(\mathrm{PO}_{4}\right)$ & 6 & & $\mathrm{NaHPO}_{3} \mathrm{NH}_{2}$ & 6 \\
\hline & $\left(\mathrm{Al}_{0.29} \mathrm{Ga}_{0.71}\right)\left(\mathrm{PO}_{4}\right)$ & 3 & & $\left(\mathrm{Al}_{0.29} \mathrm{Ga}_{0.71}\right)\left(\mathrm{PO}_{4}\right)$ & 6 \\
\hline & $\mathrm{NaPO}_{3} \mathrm{NH}_{3}$ & 3 & & $\mathrm{FePO}_{4}$ & 2 \\
\hline & $\mathrm{NaHPO}_{3} \mathrm{NH}_{2}$ & 3 & \multirow[t]{7}{*}{11} & $\mathrm{AlPO}_{4}$ & 32 \\
\hline & $\mathrm{Na}_{3} \mathrm{P}$ & 3 & & $\mathrm{CsAl}_{3}\left(\mathrm{P}_{3} \mathrm{O}_{10}\right)_{2}$ & 30 \\
\hline & $\mathrm{FePO}_{4}$ & 2 & & $\mathrm{Li}\left(\mathrm{Fe}_{0.06} \mathrm{Mn}_{0.94}\right)\left(\mathrm{PO}_{4}\right)$ & 17 \\
\hline \multirow[t]{5}{*}{5} & $\mathrm{AlPO}_{4}$ & 46 & & $\mathrm{NaPO}_{3} \mathrm{NH}_{3}$ & 7 \\
\hline & $\mathrm{CsAl}_{3}\left(\mathrm{P}_{3} \mathrm{O}_{10}\right)_{2}$ & 27 & & $\mathrm{NaHPO}_{3} \mathrm{NH}_{2}$ & 7 \\
\hline & $\mathrm{Li}\left(\mathrm{Fe}_{0.06} \mathrm{Mn}_{0.94}\right)\left(\mathrm{PO}_{4}\right)$ & 16 & & $\left(\mathrm{Al}_{0.29} \mathrm{Ga}_{0.71}\right)\left(\mathrm{PO}_{4}\right)$ & 5 \\
\hline & $\left(\mathrm{Al}_{0.29} \mathrm{Ga}_{0.71}\right)\left(\mathrm{PO}_{4}\right)$ & 7 & & $\mathrm{FePO}_{4}$ & 2 \\
\hline & $\mathrm{FePO}_{4}$ & 4 & \multirow[t]{7}{*}{12} & $\mathrm{AlPO}_{4}$ & 46 \\
\hline \multirow[t]{5}{*}{6} & $\mathrm{AlPO}_{4}$ & 52 & & $\mathrm{CsAl}_{3}\left(\mathrm{P}_{3} \mathrm{O}_{10}\right)_{2}$ & 28 \\
\hline & $\mathrm{CsAl}_{3}\left(\mathrm{P}_{3} \mathrm{O}_{10}\right)_{2}$ & 33 & & $\mathrm{Li}\left(\mathrm{Fe}_{0.06} \mathrm{Mn}_{0.94}\right)\left(\mathrm{PO}_{4}\right)$ & 10 \\
\hline & $\mathrm{Li}\left(\mathrm{Fe}_{0.06} \mathrm{Mn}_{0.94}\right)\left(\mathrm{PO}_{4}\right)$ & 7 & & $\left(\mathrm{Al}_{0.29} \mathrm{Ga}_{0.71}\right)\left(\mathrm{PO}_{4}\right)$ & 6 \\
\hline & $\left(\mathrm{Al}_{0.29} \mathrm{Ga}_{0.71}\right)\left(\mathrm{PO}_{4}\right)$ & 6 & & $\mathrm{NaPO}_{3} \mathrm{NH}_{3}$ & 4 \\
\hline & $\mathrm{FePO}_{4}$ & 3 & & $\mathrm{NaHPO}_{3} \mathrm{NH}_{2}$ & 4 \\
\hline \multirow[t]{8}{*}{7} & $\mathrm{AlPO}_{4}$ & 30 & & $\mathrm{FePO}_{4}$ & 2 \\
\hline & $\mathrm{CaDPO}_{4}\left(\mathrm{D}_{2} \mathrm{O}\right)_{2}$ & 24 & \multirow[t]{7}{*}{13} & $\mathrm{AlPO}_{4}$ & 69 \\
\hline & $\mathrm{CsAl}_{3}\left(\mathrm{P}_{3} \mathrm{O}_{10}\right)_{2}$ & 21 & & $\mathrm{NaPO}_{3} \mathrm{NH}_{3}$ & 13 \\
\hline & $\mathrm{Na}_{3} \mathrm{Mn}\left(\mathrm{PO}_{4}\right)\left(\mathrm{CO}_{3}\right)$ & 12 & & $\mathrm{NaHPO}_{3} \mathrm{NH}_{2}$ & 12 \\
\hline & $\left(\mathrm{Al}_{0.29} \mathrm{Ga}_{0.71}\right)\left(\mathrm{PO}_{4}\right)$ & 4 & & $\mathrm{FePO}_{4}$ & 4 \\
\hline & $\mathrm{NaPO}_{3} \mathrm{NH}_{3}$ & 3 & & $\left(\mathrm{Y}_{0.6} \mathrm{Ca}_{0.4}\right) \mathrm{SrBaCu}_{2.8}\left(\mathrm{PO}_{4}\right)_{0.2} \mathrm{O}_{7}$ & 2 \\
\hline & $\mathrm{NaHPO}_{3} \mathrm{NH}_{2}$ & 3 & & & \\
\hline & $\mathrm{FePO}_{4}$ & 2 & & & \\
\hline
\end{tabular}

$\mathrm{Ca}-\mathrm{P}$ (apatitic phosphorus) in the sediments from the calcareous regions were high. This may have been due to the ligand competition between $\mathrm{PO}_{4}{ }^{3-}$ and $\mathrm{CO}_{3}{ }^{2-}$ in the sediments, which would decrease the availability of binding sites on calcic complexes, because the major compositions of all sediment samples from Lake Hongfeng included
$\mathrm{CaCO}_{3}$. This was also likely caused by differences in the analysis methods employed in this study. Specifically, the sequential extraction method is based on the assumption that a particular extractant is phase or retention mode specific in its chemical attack on a mixture of forms. However, $\mathrm{XRD}$ analysis is a non-destructive technique that is 
primarily used for phase identification of a crystalline material and can provide information regarding unit cell dimensions. XRD analysis revealed that $\mathrm{AlPO}_{4}$ was present in all sediment, which was probably related to the distribution of pollution sources around the lake, such as a metallurgical company that manufactured $\mathrm{Fe}-\mathrm{Al}$ alloys.

\subsection{Methods of controlling the release of phosphorus from the sediments}

The phosphorus pollution in lakes is from external sources inside and outside the watersheds and internal sources such as the lake bottom sediments [28]. Controlling phosphorus input into the lake is extremely challenging because Guizhou is a major region in China for mining, notably by two large-scale phosphorus mining companies, Kaiyang and Wengfu, as well as for associated industries such as phosphorus fertilizer and compound mixed fertilizer manufacturing. Although these companies are not located within the watershed of the lake, application and transportation of phosphorus-related products must have had a considerable effect on the phosphorus loadings in the lake. Additionally, even if external phosphorus sources have been curtailed through various means such as the construction of sewage treatment facilities and the closing down of highly polluting production plants, the release of phosphorus from sediments is sufficient to maintain anthropogenic eutrophication for a long period in many lakes and reservoirs $[36,15]$. As a result, successful environmental management requires consideration of not only the phosphorus inputs, but also the fate of the inputs in the freshwater environment [37]. Recently, algal blooms have occurred in Lake Hongfeng and local governments are drafting a large-scale comprehensive plan to clean the lake and other local drinking-water sources. To accomplish this, there are several approaches to control the release of phosphorus from the sediment, such as dredging, sediment capping and in-situ remediation [4].

Dredging is the removal of accumulated lake sediments. However, sediment removal can have unexpected results. Accordingly, characterization of the sediment quality is crucial prior to dredging to ensure that unnecessary costs are not incurred and that there is limited environmental impact and public acceptance [38]. Unfortunately, it was not possible to obtain comprehensive information regarding the characteristics of the lake sediments in Lake Hongfeng due to its depth and location in a Karst landform [39]. Moreover, Liu et al. [40] reported that sediment dredging would cause a temporary risk of water quality deterioration in Lake Taihu. In the case of Lake Hongfeng, sediment dredging would likely destroy the equilibrium of ecological system, resulting in loss of its self-purification capacity [40]. Moreover, there are a multitude of other contaminants in the sediments, such as heavy metals, which will likely be released into the overlying water by dredging for eutrophied lakes, because lake eutrophication is favorable to reduce the heavy metal toxicity to the aquatic organisms in sediments [41]. If the sediments are removed, a new problem would arise in how they could be treated. Although the sediment sludge could be applied to agricultural land as fertilizer [42], this practice may result in the accumulation of pollutants (e.g. heavy metals) from sludge in the soil. Therefore, dredging sediments from Lake Hongfeng will probably not be a feasible method for restoration of the water body, especially for restoration of the deep water region of the lake.

In sediment capping, submerged contaminated sediments are covered by stable layers of sediment, gravel, rock, and synthetic materials. Lin et al.[43,44] reported that a compound barrier composed of zeolite and calcite with a calcite active barrier system can be used to control the release of phosphorus from sediments. However, with capping, contaminants remain in place at the site, which necessitates long-term monitoring and maintenance to ensure that they are not migrating, resulting in costs that are generally considered to be too high. Due to the distinctive geophysical characteristics, in-situ remediation also appears infeasible in this case. Thus, it is necessary to develop a novel method to restore this drinking-water source.

\section{Conclusions}

The results of XRD analysis in the present study indicated that $\mathrm{AlPO}_{4}$ was present in all sediment samples at relatively high semiquantitative concentrations. Sequential extraction revealed that the TP in the sediments primarily consisted of $\mathrm{Al}-\mathrm{P}, \mathrm{Fe}-\mathrm{P}$, and especially $\mathrm{Ca}-\mathrm{P}$ and $\mathrm{OP}$, while DP was a minor fraction. In addition, the concentrations of OP in sediments from the lake were lower than those of IP, which primarily consisted of $\mathrm{Ca}-\mathrm{P}$. Although $\mathrm{Ca}-\mathrm{P}$ may temporarily control the release of phosphorus from sediments, the release potential and bioavailability of phosphorus were still high based on the high TP in sediments from the lake. Thus, effective measures should be taken to control the release of phosphorus from sediments during lake restoration while also reducing the input of nutrients from both point and non-point sources of pollution. It should be pointed out that the results of this study were inadequate to draw a confident conclusion because of the spatiotemporal lack of homogeneity of the lake; thus, more comprehensive studies should be conducted.

This work was supported by the National Natural Science Foundation of China (20967003).

1 Xiao H Y, Liu C Q, Wang S L, et al. Organic degradation by nitrification and denitrification before diagenesis in the Hongfeng Lake, SW China(in Chinese). Geochimica, 2003, 32: 375-381

2 He T R, Feng X B, Li Z G, et al. Buildup of methyl mercury in a seasonal anoxic reservoir and impact on downstream(in Chinese). J Lake Sci, 2006, 18: 565-571

3 Zhang W, ed. Eutrophication and Environmental Characteristic 
About Lakes Hongfeng and Baihua (in Chinese). Guiyang: Guiyang Science and Technology Press, 1999. 5-23

4 Jiang C H, Hu J W, Huang X F, et al. Phosphorus speciation in sediments of Lake Hongfeng, China. Chin J Oceanol Limnol, 2011, 29: 53-62

5 Spears B M, Carvalho L, Paterson D M. Phosphorus partitioning in a shallow lake: Implications for water quality management. Water Environ J, 2007, 21: 47-53

6 Paerl H W, Valdes L M, Joyner A R, et al. Solving problems resulting from solutions: Evolution of a dual nutrient management strategy for the eutrophying Neuse River Estuary, North Carolina. Environ Sci Technol, 2004, 38: 3068-3073

7 Surridge B W J, Heathwaite A L, Baird A J. The release of phosphorus to porewater and surface water from river riparian sediments. J Environ Qual, 2007, 36: 1534-1544

8 Yu Z M, Song X X. Matrix-bound phosphine: A new form of phosphorus found in sediment of Jiaozhou Bay. Chinese Sci Bull, 2003, 48: 31-35

9 Ádám K, Krogstad T, Suliman F R D, et al. Phosphorous sorption by filtralite P-small scale box experiment. J Environ Sci Health, 2005, 40: $1239-1250$

10 Chinault S L, O'Connor G A. Phosphorus release from a biosolids-amended sandy spodosol. J Environ Qual, 2008, 37: 937-943

11 Penn C J, Bryant R B. Phosphorus solubility in response to acidification of dairy manure amended soils. Soil Sci Soc Am J, 2008, 72: 238-243

12 Conley D J, Paerl H W, Howarth R W, et al. Controlling eutrophication: Nitrogen and phosphorus. Science, 2009, 323: 1014-1015

13 Huang X F, Hu J W, Deng J J, et al. Speciation of heavy metals in sediments from Baihua Lake and Aha Lake. Asia-Pac J Chem Eng, 2009, 4: 635-642

14 Lee G, Faure G, Bigham J M, et al. Metal release from bottom sediments of Ocoee Lake No. 3, a primary catchment area for the Ducktown Mining district. J Environ Qual, 2008, 37: 344-352

15 Zhu G W, Qin B Q, Gao G. Direct evidence of phosphorus outbreak release from sediment to overlying water in a large shallow lake caused by strong wind wave disturbance. Chinese Sci Bull, 2005, 50: 577-582

16 Li X G, Song J M, Yuan H M, et al. Biogeochemical characteristics of nitrogen and phosphorus in Jiaozhou Bay sediments. Chin J Oceanol Limnol, 2007, 25: 157-165

17 Milenkovic N, Damjanovic M, Ristic M. Study of heavy metal pollution in sediments from the iron gate (Danube River), Serbia and Montenegro. Pol J Environ Stud, 2005, 14: 781-787

18 Jin X C, Tu Q Y, eds. Criterion for Investigation of Eutrophication of Lakes (in Chinese). 2nd ed. Beijing: Chinese Environmental Science Press, 1990. 218-229

19 Spivakov B Y A, Maryutina T A, Muntau H. Phosphorus speciation in water and sediments. Pure Appl Chem, 1999, 71: 2161-2176

20 Yu H Q, Fang T, Xia S B, et al. Seasonal and vertical distribution of nitrogen and phosphorus in the sediment under different ecological restoration measures in the West Lake Wuli, Lake Taihu(in Chinese). J Lake Sci, 2007, 19: 683-689

21 Jiang $\mathrm{C} \mathrm{H}$, Deng $\mathrm{J} \mathrm{J}$, Hu J W, et al. Phosphorus speciation in sediments from Baihua and Aha Lakes. In: Qian X H, Qu J P eds. Book of Abstracts of the 12th Asian Pacific Confederation of Chemical Engineering Congress (ISBN 978-7-5611-4285-1). Dalian: Dalian University of Technology Press, 2008. Vol. 2, 30

22 Wan G J. Environmental process of the deep-water lakes and approach to the protection of water resources on the Yunnan-Guizhou Plateau (in Chinese). Engineering Sciences, 2009, 11: 60-71

23 Kotut K, Ballot A, Krienitz L. Toxic cyanobacteria and their toxins in standing waters of Kenya: implications for water resource use. J Wat
Health, 2006, 4: 233-245

24 Wang Y C, Wan G J, Wang S L, et al. Forms of phosphorus in sediments of Lake Baihua and Lake Hongfeng, Guizhou (in Chinese). Acta Mineralogica Sinica, 2000, 20: 273-278

25 Wang Y C, Ma M, Wan G J, et al. The phosphorus forms and depositional history in sediments of Lake Hongfeng, Guizhou Province (in Chinese). J Lake Sci, 2004, 16: 21-27

26 Jiang C H, Deng J J, Hu J W, et al. Phosphorus speciation in sediments from Lakes Baihua and Aha with a typical karstic environment, China. Adv Mater Res, 2010, 113-114: 420-424

27 Kruopiene J. Distribution of heavy metals in sediments of the Nemunas River (Lithuania). Pol J Environ Stud, 2007, 16: 715-722

28 Ruban V, López-Sánchez J F, Pardo P, et al. Harmonized protocol and certified reference material for the determination of extractable contents of phosphorus in freshwater sediments - a synthesis of recent works. Fresenius J Anal Chem, 2001, 370: 224-228

29 Huang Q H, Wang D H, Wang C X, et al. Relation between phosphorus forms in the sediments and lake eutrophication (in Chinese). China Environ Sci, 2003, 23: 583-586

30 Su Y P, Zheng D X, Zhuang Y T, et al. Phosphorus fractionations in sediments from eutrophicated lakes in Fujian Province (in Chinese). J Agro-Environ Sci, 2005, 24: 362-365

31 Moosmann L, Gächter R, Müller B, et al. Is phosphorus retention in autochthonous lake sediments controlled by oxygen or phosphorus? Limnol Oceanogr, 2006, 51: 763-771

32 Weng H X, Zhang X M, Wu N Y, et al. Environmental and biogeochemical process of accumulation of iron-phosphorus in marine sediments. Chinese Sci Bull, 2004, 49: 931-937

33 Song J M, Luo Y X, Lv X X, et al. Forms of phosphorus and silicon in the natural grain size surface sediments of the southern Bohai Sea. Chin J Oceanol Limnol, 2003, 21: 286-292

34 Wu F C, Jin X C, Zhang R Y, et al. Effects and significance of organic nitrogen and phosphorous in the lake aquatic environment (in Chinese). J Lake Sci, 2010, 22: 1-7

35 Deng J J, Huang X F, Hu J W, et al. Distribution of several microorganisms and activity of alkaline phosphatase in sediments from Baihua Lake. Asia-Pac J Chem Eng, 2009, 4: 711-716

36 Fisher M M, Reddy K R. Phosphorus flux from wetland soils affected by long-term nutrient loading. J Environ Qual, 2001, 30: 261-271

37 McDowell R W, Sharpley A N. Uptake and release of phosphorus from overland flow in a stream environment. J Environ Qual, 2003, 32: 937-948

38 Kinaci C, Inanc B, Aydin A F, et al. Quality of the bottom sediment prior to dredging in the Golden Horn of Istanbul. J Environ Sci Health, 2004, A39: 365-374

39 Huang X F, Hu J W, Li C X, et al. Heavy metals pollution and potential ecological risk assessment of sediments from Baihua Lake, Guizhou, P.R. China. Int J Environ Heal R, 2009, 19: 405-419

40 Liu A J, Kong F X, Wang D. Water quality risk assessment for sediment dredging operations, Wulihu in Taihu Lake (in Chinese). Environmental Science, 2006, 27: 1946-1952

41 Liu F, Qin F X, Hu J W, et al. Acid volatile sulfide and bioavailability of heavy metals in sediments from Hongfeng Lake (in Chinese). Acta Scientiae Circumstantiae, 2009, 29: 2215-2223

42 Nathalie K, Dupouyet S, Bonin G. Environmental risks of applying sewage sludge compost to vineyards: carbon, heavy metals, nitrogen, and phosphorus accumulation. J Environ Qual, 2002, 31: 1522-1527

43 Lin J W, Zhu Z L, Zhao J F, et al. Influencing factors of phosphorus release control from sediments by compound barrier constructed with zeolite and calcite (in Chinese). Environ Sci, 2007, 28: 397-402

44 Lin J W, Zhu Z L, Zhao J F, et al. Influencing factors of calcite active barrier system to control phosphorus release from sediments (in Chinese). Environ Sci, 2008, 29: 121-126

Open Access This article is distributed under the terms of the Creative Commons Attribution License which permits any use, distribution, and reproduction in any medium, provided the original author(s) and source are credited. 